\title{
PSYCHOLOGICAL ADAPTATION OF A SUCCESSFUL MARRIAGE
}

\author{
Fotima Imomqulova
}

Jizzakh State Pedagogical Institute, Uzbekistan

\section{ABSTRACT}

The article considers thebeginning of socio-psychological adaptation to the stability of marriage relations and highlights socio-psychological adaptations to the stability of marriage relations.

KEYWORDS:- Well-being, adaptation, adequate, personality, attitude, Kcomfort,psychoemotional,well-being, matrimony, compatibility.

\section{INTRODUCTION}

Currently the society is at the stage of changes and reorganizations in all spheres of life. These changes have affected the family system, in which marital relations are central. Interpersonal interaction of spouses is the basis of family wellbeing and psychological comfort of its members. The quality of marital relations is largely determined by the compatibility of spouses, their social and psychophysical correspondence, and the consistency of views, attitudes, and habitual forms of reaction. Marital well-being is determined by the sense of subjective satisfaction of spouses with marital relations, which affects their psycho-emotional well-being. In social psychology has significant theoretical and practical material on marital well-being, but rather little research on the marital compatibility and no study in which an integrated approach to marital compatibility plays a significant role of socio-psychological adaptation and tolerance of the spouses, which in modern conditions, are essential for an adequate functioning of the individual in society, regulating relations in the system "acceptance of others" and "selfacceptance". In marriage, the image of a psychologically mature person is in demand, capable of adequate adaptation and building constructive relationships, ensuring well-being in the psycho-emotional state and interpersonal interaction. Psychology of family life, familymarriage relations, relationships in the family, conflicts in it, divorce and its consequences psychology in subsequent years becoming the object of a wide research of sciences. From scientists-psychologists in this field G. B. Shoumarov, E. A. Morshina, E. Goziev, V. M. Karimova, M. G. Davletshin, N. A. Soginov, S. A. Okhunzhonova, A. Shozhalilov, T. M. Adizova, E. Usmanov, Kh. Karimov, Sh. Sh. Juraeva, R. S. Samarovo, O. Shamieva, N. Salaeva, F. R. Ruzikulov,.Science under the leadership of 
CURRENT RESEARCH JOURNAL OF PEDAGOGICS 2(9): 176-179,

September 2021 DOI: https://doi.org/10.37547/pedagogics-crjp-02-09-36

ISSN 2767-3278

(C)2021 Master Journals

\section{Crossref do) 8 Google}

Accepted 25th September, 2021 \& Published 30 ${ }^{\text {th }}$ September, 2021

Fayziyeva M. et al. the research work deserves attention. The importance of social-psychological adaptation in the stability of marital relations" covers the role of socio-psychological adaptation in the stability of marital relationships, the Ability to adapt is laid in the society in which the couple developed a long period With changing social conditions, the regulatory activities of spouses ensures the process of re-adapt ourselves (And Lebedev), which are agreed upon expectations (And Peter) Adaptation ensures the stability of an evolving system in the standard environment (A G Asmolov, N. N. Moiseev, And Prigozhy) It proceeds normally until the requirements of the external environment reach the adaptation barrier (JA Alexandrovsky) and a bifurcation is activated, which ensures a change in the developing system The adapted personality is able to get out of the maladapted state (AA Rean) Marriage and family adaptation is a gradual and integral process of adaptation of spouses to each other, as a result of which a stable family structure is formed and the spouses overcome the crisis periods of matrimony development (L YA Gozman, Yu E Aleshina, S V Kovalev, V ASysenko, L B. Schneider) Adaptation is based on the unity of passive-adaptive and active-transforming connections of the individual with the environment (A. L. Sventsitsky) and on self-change and the development of 12 new personal qualities (A. A. Sventsitsky). Rean) Adaptation, acceptance of others, selfacceptance, emotional comfort, internal internal locus control, dominance and escapism-integral indicators of socio-psychological adaptation (PDiamond, KRogers), the formation of which, in our opinion, determines the well-being in marriage and family relations. Marital well-being is determined by the satisfaction of spouses with marital relations. The quality of marital relations is determined through subjective feelings of satisfaction, which are not always similar in spouses.Women are more dissatisfied with marriage than men, regardless of the level of well-being in the marriage, which indicates that men are more satisfied with their marital relationships than women. There is a correlation between a high level of well-being in marriage and the manifestation of socio-psychological adaptation. The fundamental condition for wellbeing in marriage is tolerance, which is represented in the following set of psychological features : "internal locus of control", "selfacceptance" and "acceptance of others", which are high in both spouses, while"internal locus of control " dominates in men, and"selfacceptance"and" acceptance of others " in women. For marital well-being, the following characteristics of spouses are important : adaptability, the desire for dominance, emotional comfort, focus on themselves and on the cause with low values of escapism and stress accumulation .3 Men and women have character traits that contribute to well-being in marriage. In married couples with a high level of well-being in marriage, men are characterized by demonstrativeness at the level of accentuation and emotivity at the level of character traits, for women-pedantry at the level of accentuation, as well as excitability and cyclotymicity not higher than the level of character traits. Low values of dysthymia and anxiety (not higher than the level of a character trait)are a necessary condition for well-being in marriage for both men and women выше уровня черты характера). In married couples with a low level of well-being in marriageдля, men are characterized by the manifestation of emotivity at the level of a pronounced accentuated tendency, for women excitability and cyclotymia at the level of a pronounced accentuated tendency. A common pattern for both men and women in married couples with a low level of well-being is dysthymia and anxiety at the level of a pronounced accentuated tendency. In the value system of a married couple, there are both 
CURRENT RESEARCH JOURNAL OF PEDAGOGICS 2(9): 176-179,

September 2021 DOI: https://doi.org/10.37547/pedagogics-crjp-02-09-36

ISSN 2767-3278

(C)2021 Master Journals

Crossref do: 81 Google

Accepted 25th September, 2021 \& Published 30th September, 2021

similarities and tender differences in the choice of valuesFor men and women, satisfaction with marriage is associated with the following values: "happy family life", "love", "life wisdom", "joint recreation", "showing responsibility" and "absence of material difficulties" Gender differences were revealed in the fact that for men более важными such values as "independence", "self-control", "courage in defending their opinions and views", "firm will", "breadth of views" are more important For women, such values as "neatness, cleanliness and the ability to keep things and things in order", "good breeding and good manners", "education" (as a breadth of knowledge and a high general culture); "honesty", "sensitivity and care"are more important. There are differences and similarities in the system of views of spouses about the functional role purpose of a marital union, depending on the satisfaction with the marriage and the length of service of the marriage. Ideas about the purpose of a marital union for a modern well -off married couple were distributed according to the importance of a moral and psychological union, a family and parent union, an intimate and personal union, and an economic and household union. Gender differences were manifested in the fact that men are more likely to express the need for a moral, psychological and intimate personal union, while women are more likely to express the need for a family-parent and economic union. Differences in the system of views of spouses about the functional role of a marital union were manifested depending on the length of marriageIn the period of primary adaptation (from 2 to 3 years of marriage), the main motive for young well-off married couples is a moral and psychological unionIn the period of secondary adaptation (from 14 to 20 years) the main motive for Mature wealthy couples is a familyparent Union onbhavneet prosperous young and Mature couples that are least important to those and other couples were everyday problems and domestic purpose of the Union, and was designated an important value in understanding each other, care and love. Regardless of the primary and secondary adaptation in dysfunctional young and mature couples, the spouses were united by the main motivation of the economic and household purpose of the union, a decrease in the need for moral and psychological union and the least attention to intimate and personal union.

The correlation of functional and role representations of spouses about the marital union revealed 1) with an increase in the role of the moral and psychological union, thecoincidence of expectations from marriage increases and the stress component decreases, and an increase in the coincidence of expectations of spouses from marital relations accompanies an increase in satisfaction with marriage, emotional comfort and good (normal)health. well-being of the spouses, 2) increasing the role of family-parent Union reduced escapism, 3) increasing the role of an intimate and personal Union increased adaptability and emotional comfort of the spouses, 4) increasing the role of domestic Union reduced marital satisfaction and well-being of spouses. Well-being in marriage due to the relationship in a parent family, spouses, preferably with full parent family, a happy, friendly relationship of parents, spouses, democratic, friendly attitude of parents to children in the generic family, spouses, close relationship and communication between the spouses, parental family in the present time, the adoption of spouses traditions parent families.

Thus, well-being in marriage is determined by the subjective feelings of satisfaction of spouses with marital relations, which is achievable and increases if there is a compatibility of psychological, social and biological factors, the totality of which forms for each married couple 
CURRENT RESEARCH JOURNAL OF PEDAGOGICS 2(9): 176-179,

September 2021 DOI: https://doi.org/10.37547/pedagogics-crjp-02-09-36

ISSN 2767-3278

(C)2021 Master Journals

Crossref dof 81 Google

Accepted 25th September, 2021 \& Published 30 ${ }^{\text {th }}$ September, 2021

its own individual

profile of marital compatibility and coordination

of actions in the conditions of cohabitation.

\section{ReFERENCES}

1. Шоумаров Ғ.Б., Шоумаров Ш.Б. Мухаббат ва оила. - Т.: «Ибн Сино», 1994.

2. Тўраева Ў. Оилавий хаёт этикаси ва психологияси. - Т.: «Ўзбекистон», 1990.

3. Каримова В.М. Ўзбек ёшларида оила тўғрисидаги ижтимоий тасаввурлар шаклланиши: Психол. фанл. докт. ... дисс. Фарғона, 1994. -322-б.

4. Каримов Х.К. Социально-психологичские особенности супружеских конфликтов в узбекской семье: Автореф. дис...канд. психол. наук. - Т.: ТГПИ, 1994. -С. 19.

5. Салаева Н. Хоразм оилаларининг этнопсихологик хусусиятлари: Психол. фан. номз. ...дис. - Т.: ЎзМУ, 2002. -162-б.

6. Ниёзметова Г. Ўзбек оилаларида эрхотинлик муносабатлари динамикасининг ижтимоий-психологик хусусиятлари: Психолог. фан. номз. ...дис. автореф. - Т.: ТДПУ, 2010. -24-б. 